\title{
Where do we go from here?
}

\author{
J.H. BOUTON \\ The Samuel Roberts Noble Foundation \\ 2510 Sam Noble Parkway \\ Ardmore, OK 73401 \\ jhbouton@noble.org
}

\begin{abstract}
The viability of this international symposium on grass/fungal endophytes is a direct measure of the nature and strength of the underlying science itself. The symposium's past was dominated by a multidiscipline approach and a geographic focus in New Zealand, USA, and Australia, due mainly to the economic impact of tall fescue (Festuca arundinacea Schreb.) and perennial ryegrass (Lolium perenne L.) when infected with Neotyphodium endophytes. There have been many research and technological findings reported during the past five symposia, with novel endophytes as an example of one having positive on-farm impact. In the future, it is anticipated that 1) the multidisciplinary approach will continue; 2) patenting issues will cause disruptions (hopefully small) in information sharing; 3 ) funding will drive the underlying science thereby continuing a concentration of work in New Zealand, Australia, and the USA, but opportunities will arise in these major countries for collaborative research with scientists in other geographies; 4) commercialisation and on-farm use of novel endophytes will expand; 5) sequencing and gene expression data will be available for the main fungal genomes, and microarray, genomics, and transciptome approaches will grow in importance; and 6) development of a "mind map" will help identify knowledge gaps for determining endophyte effects on animals. However, it was the inspiration, leadership, confidence, and even boldness of individual scientists in the field that pushed both this symposium and the science to the level it is today. Therefore, as the symposium moves forward, younger scientists need to assume leadership roles, and then be bold and confident in pushing forward; especially with continuing the symposium.
\end{abstract}

Keywords: Neotyphodium, fungal endophytes, symposium, grasses, tall fescue, perennial ryegrass, biotechnologies

\section{Introduction}

"I know no way of judging the future but by the past". - Patrick Henry.

"I expect to spend the rest of my life in the future, so I want to be reasonably sure of what kind of future it's going to be.

That is my reason for planning".

- Charles Kettering.

"Actual knowledge of the future was never lower, but hope was never higher. Confidence will beat predictions any time."

- Will Rogers.

"When you come to a fork in the road, take it!"

- Yogi Berra

The premise of this paper is that participation in this international symposium is a direct measure of the nature and viability of the underlying science. Predicting where this symposium and the science underpinning it will go from this point is a daunting task. However, the quotes above suggest a model for predicting the future: knowledge of the past, planning for the future's eventual outcome, but having the confidence and boldness to move forward.

\section{The Past}

\section{Multi-discipline approach}

This symposium is unique due mainly to its focus on a specific group of organisms, the fungal endophytes of grasses. The many inter-related scientific disciplines, mycology, plant physiology, molecular biology, analytical chemistry, animal science, veterinary medicine, ecology, plant breeding, and agronomy, involved in studying these organisms, their interactions with their grass hosts, and their effects on consuming animals, all contribute to make this symposia most informative to any participant wishing to understand the entire state of this unique area of science.

A good example of the general discipline areas are found in the proceedings of second symposium held in Palmerston North, New Zealand. This meeting divided itself into the following areas for both plenary and contributed papers: 1) Biology and Ecology of Endophytes; 2) Taxonomy and Molecular Biology of Endophytes; 3) Chemistry of Compounds Associated with Endophyte/Grass Interactions; 4) Toxicoses in Animals and Management Strategies to Reduce the Effects of Endophyte Toxins; 5) Tolerance of Endophyte-Infected Grasses to Drought Stress, Pests and Diseases; 6) Physiology of Plant/Endophyte Interactions; and 7) Implications and Use of Endophytes in Plant Breeding. These same general areas still predominate today.

\section{Geographic focus}

Due to the importance and widespread use of the two main grass species, perennial ryegrass and tall fescue, their highly evolved interaction with the Neoptyphodium endophytes, and the economic and ecological consequences for the grass hosts infected with toxic versions of these endophytes, this symposium historically attracted interest from many areas of the world where these grasses are important agricultural species. However, at the $5^{\text {th }}$ Symposium, the importance of these grass/endophyte systems was examined across the main geographic locations where they are commercially viable.

In the USA, large areas of tall fescue makes the problem of toxicosis a major issue for both the private and public research sectors with several avenues for mitigating or solving the problem still being pursued (Fribourg \& Waller 2005). There is also increasing interest in grass-fed beef systems which should increase the use of non-toxic tall fescue. However, the methods, appropriateness, and cost of mitigating the problem for existing pastures, along with that of converting toxic pastures to non-toxic ones (even other grass/legume species), are still important issues that will require a great deal of practical research.

In Europe, toxic associations are found, but the number of toxicity cases is low with high botanical diversity offered as an explanation for this phenomenon (Zabalgogazcoa \& Bony 2005). The future importance of these associations is speculated to be as reservoirs of endophyte germplasm useful for future cultivar improvement.

In New Zealand, research emphasis on grass endophyte associations was always a high national priority, and was recently expanded to include basic biology and genomics of endophytes, 
Figure 1 Estimated acreage of Jesup MaxQ (a.k.a. MaxP in Australia) tall fescue planted during 2001-2005. Source: UGARF reports on seed sales (unpublished data from John Ingle).

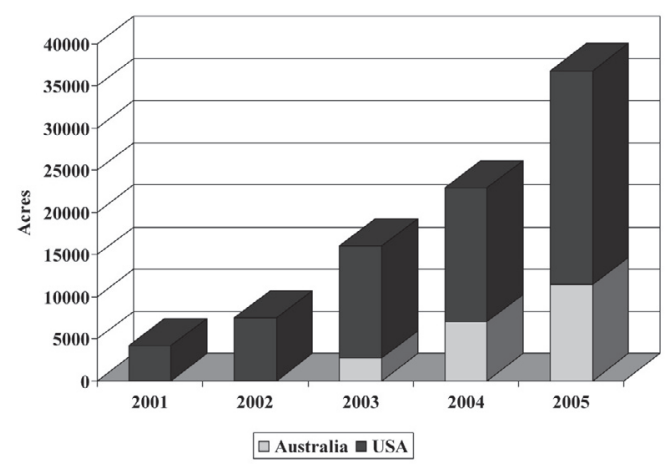

on-farm management practices, seed handling issues, and strain development work (Easton \& Tapper 2005). Support for this research comes from a mixture of private and public sources which speaks to its importance and acceptance by farmers. Basic research will continue in the future if endophyte infection is to be understood and developed further.

In Australia, the new endophyte technologies for both perennial ryegrass and tall fescue offer potential solutions to endophyte toxicity problems currently being encountered on farms (Reed et al. 2005). However, more research will be required to assess the benefits of conversions to these new technologies.

In Japan, Neotyphodium grass associations are found in native grasslands, but toxicosis problems are generally low and usually confined to use of imported straw (Sugawara et al. 2005). Although there is a potential for using endophyte infected grass as a solution to insect pest problems for the main economic crop, rice, future research will likely concentrate on "more comprehensive surveys of endophyte occurrence and novel techniques for endophyte detection and transfer".

In South America, endophyte infection is common in tall fescue and ryegrasses, but toxicosis is not a severe problem for farmers due probably to an emphasis on using non-infected seed when establishing new pastures (De Battista 2005). Using the nontoxic endophyte technologies has potential for the region, but adoption will depend on research that demonstrates agronomic and economic benefits.

The importance of endophyte associations to a countries agriculture and economic viability is therefore the main driver for geographic focus. This is because importance and impact dictates funding, and funding drives research direction. Therefore, geographic focus continues to concentrate mainly on the USA, New Zealand and Australian research programmes. This trend is supported by the fact that approximately $85 \%$ of the papers offered at this current symposium are from these countries.

\section{Impacts}

There are several important research findings and technological developments facilitated and reported at this symposium over the years. Some were summarised for the $4^{\text {th }}$ symposium (Hoveland 2000), while others happened since that time. The main ones can be generalised as follows:
Figure 2 Total number of scientific papers (plenary plus submitted) presented at each Grass/Endophyte International Symposium.

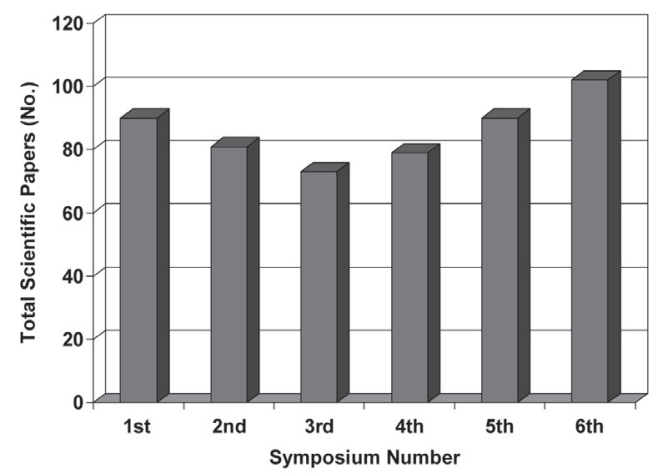

- Fungal endophyte infection occurs in many cool season grass species across diverse climatic and geographic zones, with the fungus generally assisting the host plant to achieve some level of ecological fitness, but sometimes with toxic consequences for herbivores. Neotyphodium is the predominant species investigated due to its infection of tall fescue and perennial ryegrass.

- There are very few associations described for warm season grass species.

- The taxonomy of Neotyphodium, also called Epichloe and Acremonium in past papers, and related and progenitor species demonstrate themselves to be a complex group of fungi that has evolved mainly through hybridisation.

- Neotyphodium infection in perennial ryegrass and tall fescue improves plant persistence, competitive ability, drought tolerance, pest resistance, and positively affects nutrient utilisation and tolerance to soil toxicity, but in a majority of agricultural ecosystems, are toxic to both ruminant and nonruminant animals consuming the infected forage.

- Endophyte-free tall fescue and perennial ryegrass eliminate the animal toxicosis problem, but lack persistence and pest resistance. This lack of persistence greatly reduced the agricultural use of endophyte-free forms of these grasses.

- The main alkaloid biochemical pathways, and their toxic impacts on the grazing animal, including thermoregulation, are now well described.

- Many management opportunities were investigated to eliminate or mitigate animal toxicity. These include reseeding with E- or novel endophyte varieties, dilution with legumes, controlling differential forage supply and/or stocking rates, feed treatments and dietary additives, and treatments with pharmacologic agents and immunisation.

- Improved methods for detection of endophytes and alkaloids are now available.

- The discovery and commercialisation of non-toxic Neotyphodium endophytes (e.g. novel endophytes), along with the technology for their re-infection, resulted in development of elite cultivars that are persistent, productive, and furnish excellent animal performance.

- The genes required for the production of the loline, peramine, ergovaline, and lolitrem B alkaloids are cloned and now used in basic molecular biology studies.

- The first genomics and transcriptomics resources and tools for Epichloe and Neotyphodium endophytes are now available. 


\section{Planning for the Future}

The main general areas of inquiry as described above, as well as the multi-disciplinary approach they generate, are too successful in advancing both scientific and practical progress to be abandoned at this stage. This model of multi-disciplinary scientific enquiry, and presentation at future symposia, will therefore continue in the future.

The era of patenting, as in the general biotechnology arena, is now in play, and will continue to grow for the novel endophytes and other technologies generated by the underlying science. For example, 53 total patents were issued in the USA since 1990 with $55 \%$ of those issued since 2000 when one searches under the general title "endophytes" (Patent Storm 2006). Of these 53, 14 are specific for grass/fungal associations and $64 \%$ of these were issued since 2000. This trend of increased patenting could have a negative impact on the free exchange of information so critical to any scientific discourse. People will need to file quickly and then be prepared to share information with their colleagues as soon as possible.

The amount of funding will continue to drive the underlying science, and funding usually comes from a countries strategic need to overcome a problem. Therefore, research in New Zealand, Australia, and the USA will increase and probably drive the overall science in the short run. This is mainly due to the agricultural and economic importance of the main Neotyphodium grass associations in these geographies. Research in these countries is not only increasing in number of studies, but also in sophistication with an increased use of biotechnological approaches in genomics, sequencing, and transgenics. The main factor that could affect this trend is if the study of microbial/plants mutualisms in general would expand in importance, or if there would be initiatives extrapolating the existing Neotyphodium associations into other important cropping systems such as cereals and maize. This is already happening as the patent search described above (Patent Storm 2006) revealed several patents in areas outside of the grass/Neotyphodium mutualisms. Some of these areas include taxol produced from micro-organisms and thought to be useful in cancer treatment, a novel antibioticproducing Bacillus sp. exhibits anti-fungal activity when placed into other plants, and unique nucleic acid sequences isolated from Photorhabdus luminescens provides novel insecticidal toxins.

The multi-disciplinary approach combined with geographic focusing will create opportunities for collaborations or even consortia of different organisations to develop across disciplines and/or geographies. This is also a great way to leverage resources, but its success will be driven by how focused are the main goals of the consortia. The collaborative research between the University of Georgia in the USA and AgResearch in New Zealand that resulted in the development of MaxQ tall fescue is an example of how this could work (Bouton et al. 2002). Therefore, there is no reason that an organisation in one of the major geographic regions can not collaborate with another from Europe or South America to investigate a question of mutual interest.

Commercialisation of novel endophytes will continue to expand and serve as a tangible proof of on-farm impacts especially in New Zealand, Australia, and the USA. The expansion of MaxQ sales demonstrates how much this is happening especially as a percentage of annual growth (Fig. 1). Similarly, the AR1 novel endophyte in New Zealand perennial ryegrass cultivars has already achieved a market share of nearly $60 \%$ (Lester Fletcher pers. comm.) which is astounding for a new technology based product. Simultaneously, farmer educational programs will be critical to insure proper management and overall success of novel endophytes (Roberts \& Andrae 2005). However, economic value will be the main driver (Bouton 2006). For example, Andrae \& Lacy (2004) reported that for producers currently experiencing an $80 \%$ calf crop as a result of toxic fescue pasture (e.g. $20 \%$ reduction), replacing their toxic tall fescue with MaxQ is estimated to generate net returns of \$USD55 per cow per year, and of \$USD36 per cow per year when the cost of establishment is included. These types of studies will be critical for future acceptance of the novel endophytes. Finally, maintaining viability of the non-toxic endophytes during seed production and marketing is also critical since this is the main thing the farmers are purchasing. Early results indicate special handling is required throughout the commercialisation chain to ensure success.

The availability of sequencing data of the main fungal genomes will be used to better understand mutualistic associations. Microarray, functional and comparative genomics, and metabolomic and transciptome data are already reported (DeJong et al. 2005; Spangenberg et al. 2005) and will grow in importance and use especially to answer questions on stress tolerance and especially drought tolerance. Cloning genes involved in the main alkaloid pathways also allows testing of how gene expression is regulated (Scott et al. 2005). Future work in this area will involve determining the nature of the plant's input signal for overall gene expression, and how the expression is influenced by seasonal and environmental changes.

Understanding the effects of toxic alkaloids on animal health, growth, and reproductive physiology will continue to receive a great deal of attention. The construction and use of a "mind map" by USDA-ARS (J. Strickland, unpublished) should help identify knowledge gaps in endophyte affects on animals, and will be a good tool to better plan future research. This map predicts that gaps still exist around our understanding of alkaloid effects on animal metabolism, growth and development, health, neurological impacts, and reproduction, thereby requiring future research.

\section{Moving Forward with Confidence}

The premise for this paper was participation in this international symposium is a direct measure of the nature and viability of the underlying science. The best way to judge how this has gone is to look at the number of papers presented at past and present conferences (Fig. 2). Therefore, it is a good sign that a drop in overall participation has not happened as the number of papers presented during the past years have remained high and the number at this current symposium is actually higher than the second symposium also held in New Zealand. However, it is a worry that participation from European Union countries has waned recently. This is probably due to a report that the number of toxicity cases is low in Europe (Zabalgogazcoa \& Bony 2005). This trend may have reduced opportunities from traditional EU funding sources due to a lack of strategic importance.

It is also generally agreed that two seminal papers from active, early members of this symposium greatly advanced the study of fungal endophytes/grass mutualisms. The first was the finding by Bacon et al. (1977) that Acremonium (a.k.a. Neotyphodium) endophytes in tall fescue caused fescue toxicosis in livestock, and the second was the report by Fletcher \& Harvey (1981) of a similar association of Acremonium endophytes with perennial ryegrass caused ryegrass staggers in sheep. These reports gave a platform for future work and were the drivers for organising the first symposium (Joost \& Quisenberry 1993). However, it was the inspiration, leadership, confidence, and even boldness of individual scientists in the field that pushed both this 
symposium and the science to the level it is today. Therefore, as the symposium moves forward, younger scientists need to assume leadership roles, and then be bold and confident in pushing forward, especially with continuing the symposium. If the participant and paper numbers drop, then that will be a sign that everything has run its course. Until then, everyone needs to step forward and keep participating wherever the meetings are held. Again, it is a good sign that participation and numbers of papers for this current symposium have actually increased over previous symposia (Fig. 2) and interest remains high.

\section{ACKNOWLEDGEMENTS}

Thanks to the past and present symposium organisers who provided this remarkable venue, and to all the participants who attended and gave insights and discussions over the years that shaped many of the points reflected in this paper. However, a personal thanks is extended to Garry Latch, John Hay, Charles Bacon and Carl Hoveland for mentoring my understanding of this complex area, to Tony Stratton, John Stuedemann, Nick Hill, Fred Thompson, Lester \& Carol Fletcher, Syd Easton, Mike Christensen, David Hume, Bryan Tapper, Wayne Simpson, Alison Popay, Bruce Belgrave, John Lancashire, Patty Timper, Barry Scott, Henry Fribourg and John Waller for many lively discussions, and to Carolyn Young for her insight into where biotechnology may drive us in the future.

\section{REFERENCES}

Andrae, J.; Lacy, C. 2004. Is MaxQ Economical for Cow-Calf Producers. (Available on-line at http://commodities.caes. uga.edu/fieldcrops/forages/Ga_Cat_Arc/2004/ju104.pdf). (Verified 5 December 2006).

Bacon, C.W.; Porter, J.K.; Robbins, J.D.; Luttrell, E.S. 1977. Epichloe typhina from toxic tall fescue. Applied and Environmental Microbiology 34: 576-581.

Bouton, J.H.; Latch, G.C.M.; Hill, N.S.; Hoveland, C.S.; McCann, M.A.; Watson, R.H.; Parish, J.A.; Hawkins, L.L.; Thompson, F.N. 2002. Re-infection of tall fescue cultivars with non-ergot alkaloid producting endophytes. Agronomy Journal 94: 567-574.

Bouton, J.H. 2006. Theeconomic benefits offorageimprovementin the United States. Euphytica : in press. (Available at on-line first at http://www.springerlink.com/content/5n324622300433n5/ ?p=7a75a89b5aec401ba7565ce59d29251c\&pi=0). (Verfied 5 December 2006).

De Battista, J. 2005. Current trends in South America. pp. 6574. In: Neotyphodium in Cool-Season Grasses. Eds. Roberts, C.A.; West, C.P.; Spiers, D.E. Blackwell Publishing, Ames, Iowa, USA.

DeJong, E.Z.; Smith, K.F.; Spangenberg, G.C.; Forster, J.W. 2005. Molecular genetic marker-based analysis of the grassendophyte symbiosis. pp. 123-138. In: Neotyphodium in
Cool-Season Grasses. Eds. Roberts, C.A.; West, C.P.; Spiers, D.E. Blackwell Publishing, Ames, Iowa, USA.

Easton, S.; Tapper, B. 2005. Current trends in New Zealand. pp. 35-42. In: Neotyphodium in Cool-Season Grasses. Eds. Roberts, C.A.; West, C.P.; Spiers, D.E. Blackwell Publishing, Ames, Iowa, USA.

Fletcher, L.R.; Harvey, I.C. 1981. An association of a Lolium endophyte with ryegrass staggers. New Zealand Veterinary Journal 29: 185-186.

Fribourg, H.A.; Waller, J.C. 2005. Current trends in the USA. pp. 3-22. In: Neotyphodium in Cool-Season Grasses. Eds. Roberts, C.A.; West, C.P.; Spiers, D.E. Blackwell Publishing, Ames, Iowa, USA.

Hoveland, C.S. 2000. Endophytes - research and impact. pp. 1-8. In: Proceedings of the $4^{\text {th }}$ International Neotyphodium/Grass Interactions Symposium. Eds. Paul, V.H.; Dapprich, P.D., Soest Germany.

Joost, R.; Quisenberry, S. 1993. Introduction. pp. 1-2. In: Acremonium/Grass Interactions. Eds. Joost, R.; Quisenberry, S. Elsevier Science Publishers, The Netherlands.

Patent Storm. 2006. US Patent Search. (Available Online at http://www.patentstorm.us/patents/search-results.html?se arch=endophytes\&imageField2.x $=5$ \&imageField2. $y=7$ ). (Verified 29 November 2006).

Reed, K.F.M.; Scrivener, C.J.; Rainsford, K.A.; Walker, L.V. 2005. Current trends in Australia. pp. 43-54. In: Neotyphodium in Cool-Season Grasses. Eds. Roberts, C.A.; West, C.P.; Spiers, D.E. Blackwell Publishing, Ames, Iowa, USA.

Roberts, C.; Andrae, J. 2005. Public education on tall fescue toxicosis. pp. 361-379. In: Neotyphodium in Cool-Season Grasses. Eds. Roberts, C.A.; West, C.P.; Spiers, D.E. Blackwell Publishing, Ames, Iowa, USA.

Scott, B.; Young, C.; Tanaka, A.; Christensen, M.; Tapper, B.; Bryan, G. 2005. Molecular and genetic analysis of lolitrem and peramine biosynthetic pathways in Epichloe fesctucae. pp. 93-101. In: Neotyphodium in Cool-Season Grasses. Eds. Roberts, C.A.; West, C.P.; Spiers, D.E. Blackwell Publishing, Ames, Iowa, USA.

Spangenberg, G.; Felitti, S.A.; Shields, K.; Ramsperger, M.; Tian, P.; Ong, E.K.; Singh, D.; Logan, E.; Edwards, D. 2005. Gene discovery and microarray-based transcriptome analysis of the grass-endophyte association. pp. 103-121. In: Neotyphodium in Cool-Season Grasses. Eds. Roberts, C.A.; West, C.P.; Spiers, D.E. Blackwell Publishing, Ames, Iowa, USA.

Sugawara, K.; Shiba, T.; Yamashita, M. 2005. Current trends in Japan. pp. 55-64. In: Neotyphodium in Cool-Season Grasses. Eds. Roberts, C.A.; West, C.P.; Spiers, D.E. Blackwell Publishing, Ames, Iowa, USA.

Zabalgogeazcoa, I.; Bony, S. 2005. Current trends in Europe. pp. 23-34. In: Neotyphodium in Cool-Season Grasses. Eds. Roberts, C.A.; West, C.P.; Spiers, D.E. Blackwell Publishing, Ames, Iowa, USA. 